\title{
KEBIJAKAN K3 DI RUMAH SAKIT UNTUK MENCEGAH TERJADI PAK (PENYAKIT AKIBAT KERJA)
}

\author{
Hanita Grace Sagala hanitagrace10@gmail.com
}

\begin{abstract}
ABSTRAK
Kecelakaan kerja pada perawat dianggap sebagai suatu masalah serius karena mengancam kesehatan dan kesejahteraan pasien dan petugas kesehatan secara global. (Kecelakaan tersebut yang pada akhirnya dapat mempengaruhi produktivitas kerja perawat. Produktivitas kerja yang rendah pada akhirnya berdampak terhadap pelayanan kesehatan yang diberikan oleh rumah sakit. Upaya untuk mencegah kecelakaan kerja adalah dengan menghilangkan risiko atau mengendalikan sumber bahaya dan usaha yang terakhir adalah mengunakan alat pelindung diri (APD). Pencegahan tersebut lebih diarahkan pada lingkungan kerja, peralatan, dan terutama adalah pekerja.
\end{abstract}

Kata kunci : penyakit akibat kerja, kesehatan keselamatan kerja (k3), keperawatan

\section{LATAR BELAKANG}

Pelaksanaan Kesehatan dan Keselamatan Kerja (K3) adalah salah satu bentuk upaya untuk menciptakan tempat kerja yang aman, sehat, bebas dari pencemaran lingkungan, sehingga dapat mengurangi dan atau bebas dari kecelakaan kerja dan penyakit akibat kerja yang pada akhirnya dapat meningkatkan efisiensi dan produktivitas kerja.

Kecelakaan kerja tidak saja menimbulkan korban jiwa maupun kerugian materi bagi pekerja dan pengusaha, tetapi juga dapat mengganggu proses produksi secara menyeluruh, merusak lingkungan yang pada akhirnya akan berdampak pada masyarakat luas.
Penyakit Akibat Kerja (PAK) dan Kecelakaan Kerja (KK) di kalangan petugas kesehatan dan non kesehatan kesehatan di Indonesia belum terekam dengan baik. Jika kita pelajari angka kecelakaan dan penyakit akibat kerja di beberapa negara maju (dari beberapa pengamatan) menunjukan kecenderungan peningkatan prevalensi. Sebagai faktor penyebab, sering terjadi karena kurangnya kesadaran pekerja dan kualitas serta keterampilan pekerja yang kurang memadai. Banyak pekerja yang meremehkan risiko kerja, sehingga tidak menggunakan alat-alat pengaman walaupun sudah tersedia. Dalam penjelasan undang-undang nomor 23 tahun 1992 tentang Kesehatan telah mengamanatkan antara lain, setiap tempat 
kerja harus melaksanakan upaya kesehatan kerja, agar tidak terjadi gangguan kesehatan pada pekerja, keluarga, masyarakat dan lingkungan disekitarnya.

Kecelakaan kerja pada perawat dianggap sebagai suatu masalah serius karena mengancam kesehatan dan kesejahteraan pasien dan petugas kesehatan secara global (Maria, 2015). Kecelakaan tersebut yang pada akhirnya dapat mempengaruhi produktivitas kerja perawat. Produktivitas kerja yang rendah pada akhirnya berdampak terhadap pelayanan kesehatan yang diberikan oleh rumah sakit.

Kecelakaan kerja di kalangan petugas kesehatan dan non kesehatan kesehatan di Indonesia belum terekam dengan baik. Sebagai faktor penyebab, sering terjadi karena kurangnya kesadaran pekerja dan kualitas serta keterampilan pekerja yang kurang memadai. Menurut International Labour Organitation (ILO) setiap tahun sebanyak dua juta pekerja meninggal dunia karena kecelakaan kerja yang disebabkan oleh faktor kelelahan.

Upaya untuk mencegah kecelakaan kerja adalah dengan menghilangkan risiko atau mengendalikan sumber bahaya dan usaha yang terakhir adalah mengunakan alat pelindung diri (APD). Pencegahan tersebut lebih diarahkan pada lingkungan kerja, peralatan, dan terutama adalah pekerja.

\section{METODE}

Metode dalam penulisan ini dilakukan dengan mengumpulkan data dari buku, jurnal, dan thesis dan e-book, kemudian melakukan analisis secara mendalam terkait topik yang dibahas, serta bersifat subjektif yaitu proses penulisan yang lebih fokus pada landasan teori. Dan melakukan analisis buku dan e-jurnal yang relevan dan berfokus kepada pengaplikasian berfikir kritis dalam mengelola informasi dan komunikasi keperawatan. Adapun ejurnal yang digunakan ini adalah dengan menggunakan google dengan memasukkan kata kunci “ Konsep Dasar K3”. Jurnal yang digunakan adalah jurnal yang diterbitkan 8 tahun terakhir. Adapun referensi akan dicantumkan dalam penulisan ini dengan jelas terdapat pada daftar pustaka pada bagian akhir penulis.

\section{HASIL}

Kinerja (performen) setiap petugas kesehatan dan non kesehatan merupakan resultante dari tiga komponen kesehatan kerja yaitu kapasitas kerja, beban kerja dan lingkungan kerja yang dapat merupakan beban tambahan pada pekerja. Bila ketiga komponen tersebut serasi maka bisa dicapai suatu derajat kesehatan kerja yang optimal dan peningkatan produktivitas. Sebaliknya bila terdapat ketidak serasian dapat menimbulkan masalah kesehatan 
kerja berupa penyakit ataupun kecelakaan akibat kerja yang pada akhirnya akan menurunkan produktivitas kerja.

\section{a) Kapasitas Kerja}

Status kesehatan masyarakat pekerja di Indonesia pada umumnya belum memuaskan. Dari beberapa hasil penelitian didapat gambaran bahwa 30-40\% masyarakat pekerja kurang kalori protein, $30 \%$ menderita anemia gizi dan 35\% kekurangan zat besi tanpa anemia. Kondisi kesehatan seperti ini tidak memungkinkan bagi para pekerja untuk bekerja dengan produktivitas yang optimal. Hal ini diperberat lagi dengan kenyataan bahwa angkatan kerja yang ada sebagian besar masih di isi oleh petugas kesehatan dan non kesehatan yang mempunyai banyak keterbatasan, sehingga untuk dalam melakukan tugasnya mungkin sering mendapat kendala terutama menyangkut masalah PAHK dan kecelakaan kerja.

\section{b) Beban Kerja}

Sebagai pemberi jasa pelayanan kesehatan maupun yang bersifat teknis beroperasi 8 24 jam sehari, dengan demikian kegiatan pelayanan kesehatan pada laboratorium menuntut adanya pola kerja bergilirdan tugas/jaga malam. Pola kerja yang berubah-ubah dapat menyebabkan kelelahan yang meningkat, akibat terjadinya perubahan pada bioritmik (irama tubuh). Faktor lain yang turut memperberat beban kerja antara lain tingkat gaji dan jaminan sosial bagi pekerja yang masih relatif rendah, yang berdampak pekerja terpaksa melakukan kerja tambahan secara berlebihan. Beban psikis ini dalam jangka waktu lama dapat menimbulkan stres.

\section{c) Lingkungan Kerja}

Lingkungan kerja bila tidak memenuhi persyaratan dapat mempengaruhi kesehatan kerja dapat menimbulkan Kecelakaan Kerja (Occupational Accident), Penyakit Akibat Kerja dan Penyakit Akibat Hubungan Kerja (Occupational Disease \& Work Related Diseases).

\section{PEMBAHASAN}

Kesehatan dan Keselamatan Kerja (K3) adalah upaya untuk memberikan jaminan keselamatan dan meningkatkan derajat kesehatan pekerja dengan cara pencegahan kecelakaan dan penyakit akibat kerja (PAK).

Organisasi Buruh Internasional atau International Labour Organization (ILO) merupakan suatu organisasi yang menaungi permasalahan $\mathrm{K} 3$ di tingkat dunia. Menurut ILO pelaksanaan K3 ditujukan untuk mencegah kecelakaan kerja dan penyakit yang ditimbulkan oleh suatu pekerjaan. Permasalahan K3 juga 
diatur oleh Organisasi Kesehatan Dunia atau World Health Organization (WHO).

Penerapan K3 di Indonesia diatur oleh Undang- Undang Republik Indonesia Nomor 13 Tahun 2003 tentang Ketenagakerjaan, sedangkan K3 rumah sakit (K3RS) diatur oleh KEPMENKES RI Nomor 1087/MENKES/SK/VIII/2010. K3 pada umumnya bertujuan melindungi keselamatan dan kesehatan pekerja ataupun buruh dalam mewujudkan produktivitas kerja yang optimal.

Tujuan diterapkannya K3RS adalah terciptanya cara kerja, lingkungan kerja yang sehat, aman, nyaman, dan dalam rangka meningkatkan derajat kesehatan karyawan RS. Pengetahuan K3RS yang baik diharapkan mampu menekan angka kecelakaan kerja karena individu tersebut dapat menerapakan tindakan yang sesuai dengan pengetahuan $\mathrm{K} 3$ yang dimilikinya.

Keselamatan pasien indentik dengan kualitas pelayanan, semakin baik kualitas layanan maka keselamatan pasien juga akan semakin baik.

Tujuan pengembangan program Keselamatan pasien (patient safety) di rumah sakit adalah, menciptakan budaya patient safety, memperbaiki akuntabilitas rumah sakit, melakukan pencegahan kejadian yang tidak diinginkan tidak terulang kembali .

Salah satukomponen tenaga pelayan kesehatan di rumah sakit adalah perawat.
Perawat berinteraksi langsung terhadap pasien dengan intensitas yang paling tinggi dibandingkan dengan komponen yang lainnya. Keselamatan sangat dibutuhkan oleh perawat saat bekerja. Keselamatan merupakan salah satu kebutuhan dasar manusia yang harus dipenuhi.

Manajemen rumah sakit bertanggung jawab untuk membuat program manajemen risiko yang berkelanjutan untuk mengurangi dan mengidentifikasi kejadian yang tidak diinginkan dan risikorisiko keselamatan lainnya pada pasien dan staf rumah sakit. Perawat seringkali kurang peduli terhadap bahaya di tempat kerja dan dalam melakukan upaya proteksi diri meskipun perawat tahu hal tersebut dapat membahayakan keehatan dan nyawa perawat.

Perilaku perawat dalam bekerja dipandu melalui pedoman kerja. Selain standar operasional prosedur (SOP) dan standar asuhan keperawatan (SAK) sebagai pedoman perawat dalam bekerja, panduan keselamatan perawat diperlukan untuk memandu perawat berperilaku aman dan selamat dalam bekerja. Oleh karena itu, protokol keamanan untuk perawat dan pasien harus diikuti dan dipraktikkan dengan baik.

Pada hakekatnya Keselamatan dan Kesehatan Kerja (K3) merupakan suatu usaha untuk menciptakan perlindungan dan keamanan dari berbagai risiko 
kecelakaan dan bahaya, baik fisik, mental maupun emosional terhadap pekerja, perusahaan, masyarakat dan lingkungan.

Disamping itu, keselamatan dan kesehatan kerja diharapkan dapat menciptakan kenyamanan kerja dan Keselamatan kerja yang tinggi.

\section{Pemicu penyakit karena kerja}

Bahaya potensial yang dapat menyebabkan penyakit akibat kerja (PAK) yang terjadi di rumah sakit, umumnya berkaitan dengan :

1.faktor biologi (kuman patogen yang umumnya berasal dari pasien, seperti bakteri, viral diseases, parasitic diseases dan sebagainya)

2.faktor kimia (pemaparan dalam dosis kecil namun terus menerus seperti antiseptik pada kulit, gas anestesi pada hati, debu yang bisa menyebabkan pneumoconioses dan sebagaimya, uap serta gas beracun yang bisa mengakibatkan keracunan)

3.faktor ergonomi (Tempat kerja, alat kerja yang tidak ergonomis, langkah kerja yang salah, konstruksi yang salah hingga bisa mempunyai dampak kelelahan pada tubuh, seperti tata cara duduk, tata cara mengankat pasien)

4.faktor fisik dalam dosis kecil yang terus menerus (suhu udara panas, listrik tegangan tinggi, dan radiasi)

5.faktor psikologis ( hubungan kerja antar karyawan atau atasan serta tata cara kerja di kamar bedah, dibagian penerimaan pasien, di unit gawat darurat dan ruang perawatan.)

Penyakit karena kerja serta kecelakaan kerja dikalangan petugas kesehatan serta non kesehatan di lingkungan rumah sakit belumlah terselesaikan dengan baik, hingga berlangsung kecenderungan penambahan prevalensi.

Dalam perihal ini perlu mendapatkan perhatian, sebab seseorang yang bekerja bila mengalami kecelakaan atau penyakit karena kerja tidak hanya punya pengaruh pada diri sendiri, tapi ikut produktifitas kerja mengalami penurunan dalam pemberian service kesehatan yang optimal pada pasien.

\section{Upaya pencegahan}

1. Melakukan pencatatan kejadian Kecelakaan Akibat Kerja (KAK) sesuai dengan prosedur yang ditetapkan oleh petugas K3. Seperti yang tercantum dalam Permenaker No. 03 Tahun 1998 
menyatakan bahwa pengurus atau pengusaha wajib melaporkan tiap kecelakaan yang terjadi di tempat kerja. Penyampaian laporan dapat dilakukan secara lisan sebelum dilaporkan secara tertulis.

2. Perlu dilakukan peningkatan terhadap penerapan pelayanan kesehatan kerja terutama pada pemeriksaan kesehatan khusus, pengobatan dan perawatan bagi penderita yang sakit, pemantauan lingkungan kerja serta ergonomi dan evaluasi pencatatan serta pelaporan kepada Direktur Rumah Sakit.

3. Perlu diadakan pemeriksaan kesehatan sebelum bekerja seperti pemeriksaan paru-paru, laboratorium maupun pemeriksaan secara fisik terhadap perawat IGD maupun tenaga medis yang lain.

4. Perlu diadakan penyesuaian terhadap peralatan kerja SDM Rumah Sakit seperti mengidentifikasi ergonomi terhadap peralatan kerja dan risiko peralatan kerjanya.
Seperti yang tercantum dalam Kepmenkes RI No. 1087 Tahun 2010 tentang standart kesehatan dan keselamatan kerja (K3) di Rumah Sakit bahwa penyesuaian terhadap peralatan kerja SDM dikatakan sudah diterapkan apabilah telah melakukan :

1. Identifikasi dan penilaian risiko ergonomi terhadap perlatan kerja dan SDM Rumah Sakit.

2. Membuat program pelaksanaan kegiatan, mengevaluasi dan mengendalikan risiko ergonomi.

Pentingnya penyesuaian peralatan kerja SDM adalah untuk menghindari Penyakit Akibat Kerja (PAK) dan Kecelakaan Akibat Kerja (KAK) yang disebabkan karena golongan ergonomi (penyakit yang disebabkan karena prinsip- prinsip peralatan kerja, proses kerja dan tempat kerja) misalnya nyeri otot, kelelahan fisik, deformitas tulang, dislokasi dan kecelakaan).

\section{PENUTUP}

Sebagai suatu sistem program yang dibuat bagi pekerja maupun pengusaha, kesehatan dan keselamatan kerja atau K3 diharapkan dapat menjadi upaya preventif terhadap timbulnya kecelakaan kerja dan penyakit akibat hubungan kerja dalam lingkungan kerja. Pelaksanaan K3 diawali dengan cara mengenali hal-hal yang berpotensi menimbulkan kecelakaan kerja dan penyakit akibat hubungan kerja, dan 
tindakan antisipatif bila terjadi hal demikian. Tujuan dari dibuatnya sistem ini adalah untuk mengurangi biaya perusahaan apabila timbul kecelakaan kerja dan penyakit akibat hubungan kerja. Peran tenaga kesehatan dalam menangani korban kecelakaan kerja adalah menjadi melalui pencegahan sekunder ini dilaksanakan melalui pemeriksaan kesehatan pekerja yang meliputi pemeriksaan awal, pemeriksaan berkala dan pemeriksaan khusus. Untuk mencegah terjadinya kecelakaan dan sakit pada tempat kerja dapat dilakukan dengan penyuluhan tentang kesehatan dan keselamatan kerja.

\section{DAFTAR PUSTAKA}

Anita, D. (2012). DASAR

KESELAMATANDAN KESEHATAN

KERJA. Jember : UPT Penerbit UNEJ

Ivana, A.(2014). Analisa Komitmen

Manajemen Rumah Sakit (RS) Terhadap

Keselamatan Dan Kesehatan Kerja (K3)

Pada RS Prima Medika Pemalang.

Semarang : JURNAL KESEHATAN

MASYARAKAT

Mulyono, M. Hadi dkk. (2012). Faktor

Yang Berpengaruh Terhadap

Kinerja Perawat di RS Tingkat

III. 16. 06. 01. Jurnal AKK. Vol 2 No. 1.

Nurmalia, Devi. (2012). Pengaruh
Program Mentoring Keperawatan terhadap Penerapan Budaya Keselamatan Pasien di Ruang Rawat Inap Rs. Sultan Angung Semarang. Tesis. FKM UI

Permadhi, A. (2013). Hubungan Budaya

Keselamatan Pasien Dalam Pelayanan Keperawatan dan Insiden Keselamatan Pasien di Instalasi Rawat Inap RSD dr. Soebandi. Skripsi. Jember.

Rejeki Sri .(2016).Kesehatan dan Keselamatan Kerja. Kementrian Kesehatan Republik Indonesia

Reno Afriza Neri, Y. L. (2018).

ANALISIS PELAKSANAAN SASARAN KESELAMATAN. Artikel Penelitian Jurnal Kesehatan Andalas , 51-52

Simamora, R. H. (2018). Buku ajar keselamatan pasien melalui timbang terima pasien komunikasi efektif: SBAR. Medan: USUpress.

Simamora, R. H. (2019). Buku ajar pelaksanaan identifikasi pasien. Uwais inspirasi Indonesia

Salmawati, L (2015). HUBUNGAN

PENERAPAN SISTEM MANAJEMEN

KESELAMATAN DAN KESEHATAN

KERJA DENGAN MOTIVASI KERJA

DAN STRES KERJA PADA PERAWAT 
DI RUMAH SAKIT UMUM

ANUTAPURA PALU. Palu : JURNAL MANAJEMEN

PELAYANAN

KESEHATAN.

Yuliandi, C.D.(2019) PENERAPAN

KESELAMATAN DAN KESEHATAN

KERJA (K3) DI LINGKUNGAN KERJA

ALAI INSEMINASI BUATAN (BIB)

LEMBANG. Lembang : Manajerial. 